HASANUDDIN

JOURNAL OF SOCIOLOGY

[HIS]

volume1, Issue 1, 2019

\title{
Interaksi Sosial dalam Pendekatan Saintifik Kurikulum 2013 (Studi Kasus di SMA Kristen Pelita Kasih Makassar)
}

\author{
Social Interaction in the Scientific Approach of the 2013 Curriculum (A Case Study at SMA \\ Kristen Pelita Kasih, Makassar)
}

\section{Maria Inmakulata Boina ${ }^{1}$, Mansyur Radjab², Sakaria ${ }^{3}$}

${ }^{1}$ Mahasiswa Magister Sosiologi Fisip Universitas Hasanuddin, Makassar, Indonesia, Email:mariasosiologi@gmail.com

${ }^{2}$ Dosen Departemen Sosiologi, Fakultas Ilmu Sosial dan Ilmu Politik Universitas Hasanuddin, Makassar, Indonesia, Email: radjabmansyur@ unhas.ac.id

${ }^{3}$ Dosen Departemen Sosiologi, Fakultas Ilmu Sosial dan Ilmu Politik Universitas Hasanuddin, Makassar, Indonesia, Email: sakaria@unhas.ac.id

\footnotetext{
A R T I C L E I N F O

How to Cite:

Maria Inmakulata Boina, M.

R., \& Sakaria. (2021).

Interaksi Sosial dalam

Pendekatan Saintifik

Kurikulum 2013 (Studi Kasus

di SMA Kristen Pelita Kasih

Makassar). Hasanuddin

Journal of Sociology (HJS),

3(1), 17-28.

Keywords:

Social Interaction, Saintific

Approach, 2013 Curriculum

Kata Kunci :

Interaksi Sosial, Pendekatan

Saintifik, Kurikulum 2013

* Corresponding author. Telp.: -

E-mail address: mariasosiologi@gmail.com
}

\begin{abstract}
A B S T RA C T
The scientific learning approach is one of the requirements in the implementation of the 2013 Primary and Secondary Education Curriculum (K-13), which has been established by the Government of the Republic of Indonesia. The scientific approach is essentially an effort to enhance the active role of students and the ability of teachers as facilitators in the learning process. This research was conducted using the perspective of the Bergerian Social Construction Theory, aimed to: (1) knowing the aspects of social interaction in the process of internalizing, externalizing, and objectifying of the $K-13$ scientific approach in the SMA Kristen Pelita Kasih; (2) find out the supporting and inhibiting factors of social interaction in the K-13 construction; and (3) formulating ways to accelerate the $K-13$ construction process. The results showed that (1) intense social interaction occurred in the process of constructing the K-13 scientific approach in SMA Kristen Pelita Kasih; (2) several supporting and inhibiting factors have been identified; (3) efforts to accelerate the process of constructing the K-13 include increasing the ability of teachers as facilitators and rearranging the composition of subject matter based on their scope and level of difficulty.
\end{abstract}

\section{ABSTRAK}

Pendekatan pembelajaran saintifik merupakan salah satu syarat pelaksanaan Kurikulum Pendidikan Dasar dan Menengah Tahun 2013 


\begin{abstract}
(K-13) yang telah ditetapkan Pemerintah Republik Indonesia. Pendekatan saintifik pada hakikatnya merupakan suatu upaya untuk meningkatkan peran aktif siswa dan kemampuan guru sebagai fasilitator di dalam proses pembelajaran. Penelitian ini dilaksanakan menggunakan perspektif Teori Konstruksi Sosial Bergerian, bertujuan untuk: (1) mengetahui aspek interaksi sosial di dalam proses internalisasi, eksternalisasi, dan obyektifikasi pendekatan saintifik K13 di SMA Kristen Pelita Kasih; (2) mengetahui faktor penunjang dan penghambat interaksi sosial di dalam pengkonstruksian K-13; dan (3) merumuskan cara untuk mempercepat proses pengkonstruksian K-13. Hasil penelitian menunjukkan bahwa (1) terjadi interaksi sosial yang intens di dalam proses pengkonstruksian pendekatan saintifik K-13 di SMA Kristen Pelita Kasih; (2) telah diidentifikasi beberapa faktor penunjang dan faktor penghambat; (3) upaya untuk mempercepat proses pengkonstruksian K13 di antaranya dengan cara peningkatan kemampuan guru sebagai fasilitator dan penyusunan ulang komposisi materi pelajaran berdasarkan cakupan dan tingkat kesulitannya.
\end{abstract}

\title{
1. PENDAHULUAN
}

Pemerintah melalui Menteri Pendidikan dan Kebudayaan telah mengeluarkan kebijakan berupa penetapan standar proses pendidikan dasar dan menengah melalui Peraturan Mendikbud (Permendikbud) Nomor 22 tahun 2016. Salah satu penetapannya adalah penggunaan Pendekatan Saintifik (Ilmiah) dalam proses pembelajaran di sekolah(Mendikbud RI, 2016). Istilah "pendekatan saintifik" atau "pembelajaran berbasis pendekatan ilmiah" (Komara, 2016) mengacu pada suatu aktivitas yang umum dalam dunia ilmu pengetahuan, yaitu "metode ilmiah" (Sani, 2017). Pendekatan saintifik yang tercantum di dalam K-13(Mendikbud RI, 2013), terdiri dari beberapa langkah kerja yaitu: mengamati, menanya, mencoba / mengumpulkan informasi, menalar, dan mengkomunikasi. Langkah kerja tersebut mengacu pada rumusan menurut Dyer dan kawan - kawan (Dyer, Gregersen, \& Christensen, 2011) pada intinya mementingkan proses, interaksi di antara siswa, dan bertujuan meningkatkan kreativitas peserta didik di dalam proses pembelajaran (Mendikbud RI, 2016).

Ada beberapa penelitian tentang pendekatan saintifik telah dilakukan. M.N. Fahmi telah melakukan penelitian terhadap siswa SD di Ngawi menyimpulkan bahwa pendekatan saintifik dalam mata pelajaran (Mapel) Ilmu Pengetahuan Sosial (IPS) mampu meningkatkan interaksi sosial di antara peserta didik sekaligus meningkatkan ketuntasan klasikal secara signifikan. Interaksi sosial terjadi sebanyak 97\% dan tingkat ketuntasan klasikal mencapai 95\% dari standar masing - masing 80\% (Fahmi, 2017). Sebuah penelitian lainnya dilakukan oleh M.W. Setiyadi dkk di beberapa SMA di Kabupaten Gowa Provinsi Sulawesi Selatan menyimpulkan bahwa terjadi peningkatan interaksi sosial dan ketuntatas klasikal dalam Mapel Biologi (Setiyadi, Ismail, \& Gani, 2017). Hurst dkk melakukan riset kepada 180 siswa dan mereka semua menerima adanya interaksi sosial di dalam proses 
pembelajaran. Menurut para siswa, dampak interaksi sosial terhadap pembelajaran adalah (a) membantu siswa belajar dari orang lain (23\%), (b) membuat belajar menjadi menyenangkan (16\%), (c) membuat siswa tertarik dan terlibat (10\%), (d) memungkinkan siswa mendapat kesempatan untuk berbicara di kelas ( $8 \%$ ), dan selebihnya (43\%) adalah berbagai jawaban positif seperti "meningkatkan pemahaman, membuat kelas menjadi lingkungan belajar, membantu siswa menjadi nyaman dan percaya diri, mempersiapkan siswa untuk dunia nyata, membantu siswa mengembangkan keterampilan sosial, dan lain - lain.

Ketiga penelitian di atas menunjukkan bahwa pelaksanaan pendekatan saintifik di dalam proses pembelajaran akan meningkatkan interaksi sosial sekaligus meningkatkan ketercapaian tujuan pembelajaran. Interaksi sosial dalam pendidikan dapat diartikan sebagai suatu bentuk dialog yang bermakna di antara peserta didik(Hurst, Wallace, \& Nixon, 2013). J.P. Gee (2001) berpendapat "membaca dan menulis tidak dapat dipisahkan dari berbicara, mendengarkan, dan berinteraksi, di satu sisi, atau menggunakan bahasa untuk berpikir tentang dan bertindak atas dunia, di sisi lain" (Gee, 2001, p. 714). Sedangkan menurut Y.S. Okita, Interaksi sosial memainkan peran penting dalam pembelajaran. Berinteraksi dengan orang lain telah terbukti sangat efektif dalam membantu siswa untuk mengatur pikiran mereka, merefleksikan pemahaman mereka, dan menemukan celah (gaps) dalam alasan mereka. Dalam pengertian yang luas, interaksi sosial dan pembelajaran dapat merupakan pembelajaran sebaya, pengajaran timbal balik / dialogis, belajar dengan mengajar (learning by teaching), belajar dengan pengamatan/ observasi, belajar dengan melakukan (learning by doing), dan pemantauan diri sendiri. (Okita, 2012).

Namun demikian, masih sering dijumpai kendala - kendala yang di alami guru maupun siswa dalam mengimplementasikan pendekatan saintifik di dalam proses pembelajaran. Alex Chandra dkk telah melakukan riset terhadap Kelas XI IPS di SMA Katolik Talino, melaporkan bahwa komunikasi dan kontak sosial yang terjadi dalam pembelajaran sosiologi belum berlangsung dengan baik(Chandra, Yusuf, \& Rustiyarso, 2013). Peneliti lainnya, yaitu Herawati dan Suherman melaporkan bahwa kesulitan yang paling sering dialami siswa adalah kurangnya waktu untuk memahami suatu materi pembelajaran di bandingkan teman - temannya yang lain(Herawaty \& Suherman, 2018). Kendala lain adalah kurangnya motivasi siswa untuk belajar maupun mengikuti proses pembelajaran di sekolah.

Mencermati pentingnya interaksi sosial dalam pendekatan saintifik serta kendala - kendala yang muncul di dalam pelaksanaannya, maka penulis tertarik untuk meneliti fenomena ini secara lebih mendalam. Kami menggunakan perspektif Teori Konstruksi Sosial Bergerian(Berger \& Luckmann, 1990), yaitu melihat suatu proses terbentuknya konstruksi sosial dalam tahap internalisasi, obyektivasi atau pelembagaan, dan eksternalisasi, untuk mengkaji obyek penelitian tersebut lebih mendalam dan 
terperinci. Untuk itu, kami merumuskan tujuan penelitian sebagai berikut: (1) mengetahui aspek interaksi sosial di dalam proses internalisasi, eksternalisasi, dan obyektifikasi pendekatan saintifik K13 di SMA Kristen Pelita Kasih; (2) mengetahui faktor penunjang dan penghambat interaksi sosial di dalam pengkonstruksian K-13; dan (3) merumuskan cara untuk mempercepat proses pengkonstruksian K-13.

\section{METODE PENELITIAN}

Analisis data dilakukan secara kualititatif deskriptif karena penulis ingin mengulas fakta - fakta yang ditemukan. Pembahasan dilakukan pertahapan proses dimulai dari internalisasi, ekseternalisasi, dan obyektivasi sesuai Teori Konstruksi Sosial Bergerian untuk dapat menghubungkan satu fakta dan fakta lainnya, sehingga hubungan sebab akibatnya menjadi lebih jelas. Dengan demikian, penulis dapat lebih mudah menemukan akar masalah dari kendala - kendala yang muncul dan dapat merumuskan usulan - usulan untuk mengatasi kendala tersebut.

Penilitian ini dilaksanakan di Sekolah Menengah Atas (SMA) Kristen Pelita Kasih di Kota Makassar Provinsi Sulawesi Selatan. Sekolah ini telah melaksanakan K-13 sejak pertama ditetapkan oleh Kemdikbud pada semester awal Tahun Ajaran 2014 / 2015. Kemudian pelaksanaan K-13 terhenti atau kembali ke Kurikulum sebelumnya yaitu KTSP, namun pada semester awal Tahun Ajaran 2017 / 2018, K-13 kembali diberlakukan di sekolah ini. Waktu pelaksanaan penelitian selama satu bulan yaitu pada bulan Agustus 2018.

Informan pada penelitian ini adalah guru dan siswa SMA Kristen Pelita Kasih. Populasi guru sejumlah 16 (enam belas) orang yang mengampu 17 (tujuh belas) mata pelajaran dan sebagai Guru Bimbingan dan Konseling sebanyak 1 (satu) orang. Informan dipilih sebanyak 5 (lima) orang berdasarkan kriteria antara lain antara lain, yaitu: sudah mengikuti Bimbingan Teknis (Bimtek) K-13 dan telah bertugas lebih dari 2 (dua) tahun di SMA Kristen Pelita Kasih. Informan guru yang terpilih, yaitu ET, RJ, MT. MG dan CM. Mengampu mata pelajaran Pendidikan Pancasila dan Kewarganegaraan (PPKN) merangkap Geografi, Pendidikan Agama Kristen, Matematika, Kimia, dan Bahasa Inggeris.

Sampel atau informan siswa sebanyak 7 (tujuh) orang dari kelas XI. Jumlah siswa kelas XI adalah 30 (tiga puluh) orang. Kelas XI dipilih karena kelas ini telah menjalani K-13 selama 2 (dua) tahun sementara kelas X baru menjalani K-13 selama 1 (satu) tahun dan kelas XII belum menjalani K-13. Sedangkan 7 orang siswa tersebut dipilih secara purposive sampling dengan kriteria 2 (dua) orang dari kelompok siswa dengan nilai akademik tinggi, 3 orang siswa dari kelompok menengah dan 2 orang siswa dari kelompok nilai akademik di bawah rata - rata kelas. Siswa yang terpilih menjadi informan 
yaitu: NA, SV, GA, VC, RL, WS, dan AA.

Metode pengumpulan data dilakukan dengan 3 (tiga) cara yaitu wawancara mendalam, observasi atau pengamatan, dan studi dokumentasi. Observasi dilakukan terhadap seluruh proses sosialisasi, pelaksanaan hingga evaluasi Pembelajaran dengan Pendekatan Saintifik yang merupakan bagian tidak terpisahkan dari Kurikulum Pendidikan 2013 (K-13). Wawancara dilakukan untuk mengetahui persepsi dan pelaksanaan pendekatan saintifik di SMA Kristen Pelita Kasih. Studi dokumentasi dilakukan untuk mengetahui keadaan riil dan untuk mengkonfirmasi temuan yang diperoleh dari wawancara maupun observasi.

\section{HASIL PENELITIAN DAN PEMBAHASAN}

\subsection{Internalisasi: Interaksi sosial dalam sosialisasi K-13}

Proses sosialisasi K-13 di mana Pendekatan Saintifik ada di dalamnya berlangsung dalam beberapa tahap kegiatan. Pertama adalah sosialisasi umum yang dilakukan oleh Pemerintah dalam hal ini Dinas Pendidikan Provinsi Sulsel melalui para pengawas sekolah kepada masing - masing sekolah termasuk SMA Kristen Pelita Kasih Makassar. Tahap kedua adalah kegiatan Bimbingan Teknis yang dilakukan oleh Dinas Pendidikan Provinsi bekerjasama dengan Lembaga Peningkatan Mutu Pendidikan (LPMP) Sulawesi Selatan. Bimtek ini dilaksanakan melibatkan para guru SMA se Sulsel sesuai dengan Mata Pelajaran (Mapel). Tahap ketiga adalah pendampingan langsung kepada guru di dalam proses pembelajaran oleh Instruktur K-13 di masing - masing sekolah. Tahap keempat adalah proses sosialisasi yang dilakukan oleh para guru kepada siswa di masing - masing kelas sesuai Mapel.

Keempat tahap sosialisasi ini dilakukan dengan pendekatan saintifik di mana interaksi sosial sangat menonjol di dalam proses ini. Pemberian informasi tidak dilakukan secara searah, dari fasilitator kepada peserta saja, tetapi terjadi dua arah atau dialogis di antara fasilitator dan peserta. Demikian pula interaksi sosial di antara peserta.

Menurut hasil wawancara yang dilakukan kepada para guru dan ditopang dengan pengamatan yang dilakukan penulis, dapat dinyatakan bahwa proses internalisasi pendekatan saintifik K-13 di SMA Kristen Pelita Kasih berlangsung dengan baik dan lancar. Dikatakan baik karena prosesnya berlangsung sesusai rencana, sedangkan dikatakan lancar karena selama proses tersebut tidak dijumpai hambatan hambatan yang dapat menganggu pelaksanaannya.

Bimbingan teknis (Bimtek) K-13 yang dilaksanakan oleh LPMP Sulsel menggunakan pendekatan saintifik. Peserta Bimtek di mana para guru yang bertindak sebagai peserta dapat langsung diajak untuk mengalami dan mempraktikkannya. Selanjutnya instruktur K-13 mendampingi guru melaksanakan pembelajaran dengan pendekatan saintifik sebagai wujud pelaksanaan K-13 di sekolah. Sehingga dapat 
dikatakan bahwa keberhasilan program sosialisasi K-13 kepada SMA Kristen Pelita Kasih ditunjang oleh penggunaan pendekatan saintifik di dalam Bimtek.

\subsection{Eksternalisasi: Interaksi sosial dalam proses pembelajaran}

Setelah memperoleh pemahaman yang benar tentang pendekatan saintifik sesuai K-13, maka para guru melaksanakan proses pembelajaran Menurut pengakuan beberapa orang guru, pendekatan saintifik telah dilaksanakan sesuai auturan yang termaktub di dalam K-13.

Menurut informasi yang dikemukakan oleh para guru dalam wawancara, terungkap bahwa proses pembelajaran menggunakan pendekatan saintifik di sekolah yang diteliti relatif berhasil. Informan guru ET mengemukakan:

"Sebagian pokok bahasan sudah menggunakan pendekatan saintifik dan ini sangat membantu meningkatkan keaktifan siswa di kelas.”

Informan guru MG juga mengatakan:

"Ya, (kami sudah) menggunakan metode saintifik. Dalam pembelajaran kimia, perlu menerapkan pembelajaran dengan model saintifik. Misalnya bagaimana observasi, mengolah, mengambil kesimpulan dan menerapkannya dalam kehidupan sehari - hari. (Mapel) Kimia banyak praktik, merupakan pendekatan saintifik. Misalnya: bahan sudah disiapkan oleh siswa, siswa diminta untuk mempelajari materi yang berkaitan dengan praktikum sebelum masuk laboratorium. Siswa kemudian diminta untuk membuat laporan akhir. Skemanya adalah, mengemukakan teori pendukung, kemudian membandingkan teori dengan hasil praktikumnya".

Informan guru CM memberi keterangan:

Ya, untuk pelajaran Bahasa Inggeris, sudah menggunakan metode saintifik. Pertama dalam hal menanya, memberi / merangsang siswa sampai sejauh mana mereka memahami. Kedua, siswa diminta juga untuk mengkomunikasikan tentang materi atau informasi yang diberikan. Dan ketiga dengan cara mengamati gambar dan pemutaran video. Serta beberapa kegiatan lainnya yang memberi kesempatan agar siswa lebih banyak speaking.

Informan guru RJ menyatakan:

Untuk pelajaran yang saya ajar yaitu Agama Kristen, lebih mengutamakan pendekatan saintifik, cocok sekali. Biasanya kami akan membahas suatu topik kemudian siswa ditugaskan untuk membahas topik tersebut berdasarkan bacaan dari Alkitab, setelah itu mereka mempresentasikan di depan kelas. Bila waktu mencukupi, akan diberi kesempatan untuk tanya jawab dengan kelompok yang mempresentasi.

Pernyataan informan - informan guru di atas sejalan dengan yang dikemukakan oleh para informan siswa. Berikut ini kami kutip beberapa jawaban siswa atas pertanyaan: "Apakah peserta didik merasa 
bahwa interaksi antara siswa dan siswa di dalam proses pembelajaran menjadi lebih meningkat dengan adanya pendekatan saintifik?" Semua informan siswa menjawab "Iya". Terjadi peningkatan interaksi antara para siswa di dalam proses pembelajaran. Bentuknya berupa diskusi kelompok dan diskusi kelas. Dalam diskusi kelas, ada kelompok yang mempresentasikan hasil temuannya. Di dalam diskusi kelompok, siswa saling membantu dalam menemukan jawaban - jawaban. Hal ini sejalan dengan hasil penelitian yang dilaksanakan oleh Muhammad Nahdi Fahmi (2017), Ridwan Abdullah Sani (2017), dan Adisti Putri dkk (Putri, Utami, \& Nugroho, 2015).

Selanjutnya ketika diberi pertanyaan, apakah interaksi sosial di dalam pembelajaran meningkatkan pemahaan anda terhadap materi pembelajaran, para informan siswa menjawab iya. Demikian pula ketika ditanya tentang hubungan antara penggunaan pendekatan saintifik dalam pembelajaran dengan pembentukkan sikap, para informan menjawab bahwa penggunaan pendekatan saintifik meningkatkan sikap sosial. Suasana pembelajaran yang interaktif meningkatkan pemahaman terhadap materi pelajaran sekaligus meningkatkan keterampilan sosial. Hasil ini juga sejalan dengan penelitian yang telah dilakukan oleh Setiyadi dkk, dan Beth Hurst dkk (2017)

Namun demikian ada kendala yang muncul dalam pelaksanaan pendekatan saintifik di kelas - kelas. Menurut beberapa informan guru, mereka kadang - kadang terkendala karena waktu pembelajaran dianggap kurang bila dibandingkan dengan cakupan materi yang dialokasikan. Menurut beberap informan tersebut, siswa kadang kala tidak menggunakan waktu diskusi secara efisien. Informan (guru) MT mengemukakan:

"Kadang - kadang siswa malas untuk aktif dan hanya mengandalkan jawaban temannya saja. Guru mau membimbing siswa tetapi terdesak waktu. Siswa yang sudah mengerti akan cepat bosan karena materinya lambat."

Informan guru lainnya, yaitu ET mengemukakan:

"Kesiapan di dalam pembelajaran yaitu mencari referensi. Siswa sering kesulitan mencari refensi. Sarana dan prasarana cukup mendukung namun lebih baik lagi bila ditambah yaitu jaringan Wi-fi dan teman - teman seprofesi saling membantu."

Sedangkan dari sisi para siswa, informasi yang diberikan berbeda. Ketika penulis mengajukan pertanyaan tentang apakah siswa mengalami kesulitan dalam memahami materi pembelajaran di K-13, beberapa siswa menjawab bahwa materi - materi pembelajaran di dalam K-13 lebih sulit. Siswa NA dan VC menjawab "Iya".

NA: "Ya, menurut saya ada beberapa pelajaran yang materinya susah dan kita diharuskan untuk mencari atau memahami sendiri materinya.

VC: Iya, terkadang saya bertemu dengan materi yang sulit atau juga ketika guru memberi tugas, 
tetapi bahannya kurang dijelaskan di dalam buku cetak.

Namun ada juga yang menyatakan tidak. Siswa SV dan RL menjawab "tidak":

SV : Tidak juga, karena semua yang dijelaskan oleh guru ada dalam buku, jadi jika mengalami kesulitan bisa mencari di buku atau di internet dan bisa juga bertanya langsung kepada guru.

RL: Tidak ada. Karena apa yang diarahkan dan dijelaskan guru sesuai dengan yang ada di buku.

Secara ringkas dapat dikatakan bahwa kendala - kendala yang muncul dalam pelaksanaan pendekatan saintifik K-13 di SMA Kristen Pelita Kasih adalah sebagai berikut: kurangnya waktu untuk mendalami satu topik materi, atau dengan kata lain pokok bahasan terlalu banyak sehingga waktu siswa untuk mendalaminya menjadi kurang. Kendala lain menurut persepsi guru adalah rendahnya motivasi siswa dan kesiapan atau keseriusan untuk mencari sumber materi. Sedangkan kendala siswa adalah kadang - kadang materi dirasakan terlalu sulit.

\subsection{Obyektivasi: Interaksi sosial di dalam pelembagaan K-13}

Pelembagaan K-13 di mana pendekatan saintifik temasuk di dalamnya meliputi penetapan beberapa kebijakan dan peraturan dalam lingkup SMA Kristen Pelita Kasih yang menjamin terlaksananya K-13. Pertama adalah SMA Kristen Pelita Kasih memberlakukan pelaksanaan K-13 pada kelas X pada Tahun Ajaran 2017/2018, dilanjutkan pada Tahun Ajaran berikutnya diberlakukan pada kelas X dan XI, dan seterusnya berlaku untuk semua kelas yaitu X, XI dan XII. Kedua adalah kewajiban bagi guru untuk menyusun dan menggunakan perangkat pembelajaran (14 komponen). Ketiga adalah kewajiban menggunakan pendekatan saintifik dalam proses pembelajaran. Keempat adalah penilaian pengetahuan, keterampilan, sikap spiritual dan sikap sosial secara deskriptif. Kelima adalah penyediaan buku sesuai K-13. Keenam adalah penyediaan fasilitas seperti jaringan internet dan peralatan teknologi informasi untuk mendukung pelaksanaan K-13. Ketujuh adalah penyediaan forum konsultasi dan diskusi bagi guru - guru untuk memdiskusikan pelaksanaan K-13.

Secara keseluruhan, proses pelembagaan atau obyektivasi ini berlangsung dengan baik. Dikatakan baik karena terjadi interaksi sosial yang baik di antara Kepala Sekolah, guru, siswa, dan karyawan SMA Kristen Pelita Kasih. Tidak dijumpai penolakan dan kendala yang besar sehingga pelaksanaan K-13 terganggu.

Namun demikian, berdasarkan wawancara mendalam yang dilakukan kepada informan guru, dijumpai beberapa kendala kecil menyangkut pelembagaan K-13, yaitu: pedoman penyusunan perangkat pembelajaran sering mengalami revisi, sehingga guru membutuhkan waktu dan pemikiran yang lebih untuk mengerjakannya. 


\subsection{Faktor Penunjang dan Penghambat}

Proses Konstruksi Sosial Pendekatan Saintifik K-13 di SMA Kristen Pelita Kasih berjalan dengan relatif baik karena adanya sejumlah faktor penunjang. Namun terdapat pula sejumlah faktor penghambat. Apabila faktor penunjang ditingkatkan dan faktor penghambat dapat dikurangi, maka akan terjadi peningkatan proses konstruksi pendekatan saintifik K-13.

Proses sosialisasi melibatkan semua guru dan menjangkau siswa, dilaksanakan dengan metode yang dialogis / interaktif sejalan dengan penekatan saintifik K-13 itu sendiri. Kegiatan Bimtek yang dilaksanakan berfungsi sebagai sarana sosialisasi, sekaligus pelatihan bagi guru untuk mengembangkan pendekatan saintifik (dan aspek - aspek K-13 lainnya) dalam proses pembelajaran. Proses internalisasi ini meningkatkan pemahaman dan keterampilan para guru dalam pelaksanaan K-13 sekaligus meminimalkan penolakan terhadap K-13.

Proses eksternalisasi di mana guru melaksanakan pendekatan saintifik K-13 dalam proses pembelajaran berlangsung relatif baik. Semua Mapel yang gurunya diwawancarai telah menjalankan pendekatan saintifik, walaupun ada beberapa kendala. Faktor penunjangnya berkaitan dengan keberhasilan sosialisasi seperti yang dikemukakan di atas. Fator penunjang eksternaliasi lainnya adalah adanya kemampuan guru untuk melaksanakan pendekatan saintifik tersebut, ditunjang dengan ketersediaan fasilitas yang cukup mendukung seperti jaringan internet, peralatan teknologi informasi dan komunikasi (TIK), ketersediaan buku - buku pelajaran dan suasana sekolah yang kondusif.

Kemampuan guru sangat penting untuk menjamin keberhasilan pembelajaran. Di sini guru memainkan banyak berperan, seperti pengontrol, penggerak (direktur), pengatur (menejer), fasilitator, dan salah satu sumber belajar(Nugraha \& Suherdi, 2107). Hal ini sejalan dengan penelitian yang telah dilakukan Fahmi (2017), Setiyadi dkk (2017) dan Hurst (2015). Dalam hal ini, faktor guru sangat menentukan pencapaian tujuan pembelajaran sesuai K-13.

Adapun proses obyektifikasi atau pelembagaan pendekatan saintifik K-13 berlangsung pula dengan relatif baik dan lancar. Dikatakan baik karena proses pelembagaan berlangsung relatif sesuai dengan tujuan K-13. Dikatakan lancar karena proses obyektifasi berlangsung sesuai tahapan waktu yang ditetapkan. Faktor - faktor yang mendukung terlaksananya proses pelembagaan ini adalah adanya kebijakan sekolah untuk melaksanakan K-13, adanya pendampingan dari pihak menejemen sekolah (Kepala Sekolah, Wakasek dan Instruktur K-13) kepada para guru, dan yang paling penting adalah interaksi sosial yang kondusif di antara menejemen sekolah, para guru dan siswa di dalam keseluruhan proses pendidikan di SMA Kristen Pelita Kasih.

Selain faktor penunjang proses pengkonstruksian pendekatan saintifik K-13 di SMA Kristen Pelita Kasih, kami juga mengidentifikasi beberapa faktor penghambat. 
Guru merasa bila menggunakan pendekatan saintifik, maka waktu pembelajaran yang tersedia tidak cukup untuk satu pokok bahasan. Bila dikaji lebih mendalam, waktu yang tersedia untuk setiap pokok bahasan sudah tetap yaitu 45 menit per jam pelajaran, seperti yang tercantum di dalam Lampiran Kepmendagri No. 22/ 2016 Bab IV huruf A2. Biasanya setiap pokok bahasan telah dialokasikan (pada silabus maupun RPP) untuk satu atau dua jam pelajaran. Jadi bila ada keluhan kurangnya waktu, mungkin yang lebih tepat adalah pokok bahasan yang terlalu banyak. Guru juga mengeluhkan kadang - kadang menemukan siswa kurang semangat dan fokus dalam diskusi / interaksi di dalam pembelajaran. Sementara siswa mengeluhkan kadang - kadang menemukan materi pembelajaran yang sulit.

\subsection{Upaya Mempercepat Proses Konstruksi Pendekatan Saintifik K-13}

Mengingat peran guru sebagai fasilitator di dalam proses pembelajaran berbasis pendekatan saintifik K-13, maka beberapa tindakan dapat diambil untuk mengatasi kendala tersebut. Pertama, guru memberikan petunjuk interaksi secara jelas, mengawasi satu persatu siswa sekaligus memberikan motivasi dan memberikan bantuan untuk menemukan sumber pembelajaran. Hal ini sesuai dengan saran dari Nugraha dan Suherdi (2017) yang menyatakan bahwa guru adalah pengontrol, penggerak (direktur), pengatur (menejer), fasilitator, dan salah satu sumber belajar. Kedua, pemerintah sebagai penyusun kurikulum menyusun ulang komposisi materi per mata pelajaran dengan memperhatikan keluasan cakupan materi dan tingkat kesulitan. Ketiga, diadakannya pelatihan - pelatihan atau Bimtek dengan tujuan meningkatkan kapasitas guru sebagai fasilitator dalam rangka pelaksanaan pendekatan saintifik K-13. Hal ini sejalan Peraturan Mendikbud No. 22 Tahun 2016 Tentang Standar Proses Pendidikan Dasar dan Menengah, Bab IV huruf B4.(Mendikbud RI, 2016), di mana guru diharapkan mengelola kelas atau laboratorium dengan mengacu pada sejumlah ketentuan.

\section{KESIMPULAN}

\subsection{Kesimpulan}

Ada interaksi sosial yang intens di dalam proses pengkonstruksian pendekatan saintifik K-13 di SMA Kristen Pelita Kasih; ditandai dengan`berlangsungnya proses internalisasi, eksternalisasi dan obyektifasi pendekatan saintifik K-13 sesuai yang diharapkan. Di dalam proses internaliasi terjadi interaksi sosial yang dialogis di antara pihak yang memberi sosialisasi dengan pihak yang menerima sosialisasi. Di dalam proses eksternalisasi (proses pembelajaran) terjadi interaksi sosial secara intens, di antara guru dengan siswa dan di antara para siswa, sesuai dengan pendekatan saintifik K-13. Di dalam 
proses obyektifasi (pelembagaan) pendekatan saintifik K-13 pun terjadi interaksi sosial secara intensif di antara menejemen sekolah (kepala sekolah, wakasek, instruktur K-13) dan para guru.

Faktor penunjang keberhasilan pengkonstruksian pendekatan saintifik K-13 di SMA Kristen Pelita Kasih adalah pemilihan metode yang interaktif / dialogis, adanya fasilitas pendukung yang memadai, adanya kemampuan guru sebagai fasilitor (pengelola interaksi sosial), adanya motivasi belajar sebagian besar siswa, dan adanya pendampingan dari pihak menejemen sekolah kepada para guru. Sedangkan faktor penghambat adalah tidak selesainya pendalaman suatu pokok bahasan sesuai alokasi waktu. Faktor penghambat lainnya adalah guru merasa bahwa siswa kadang kala kurang semangat dan fokus, sedangkan siswa kadang merasa materi pembelajaran terlalu sulit.

Upaya mempercepat pengkonstruksian pendekatan saintifik K-13 dapat dilakukan dengan pengadaan pelatihan - pelatihan atau Bimtek untuk meningkatkan kemampuan guru sebagai fasilitator. Di samping itu pemerintah sebagai penyusun kurikulum menyusun ulang komposisi materi per mata pelajaran dengan memperhatikan keluasan cakupan materi dan tingkat kesulitan sehingga memudahkan implementasi di dalam proses pembelajaran.

\subsection{Saran}

1) Pelatihan - pelatihan atau Bimtek kepada para guru untuk meningkatkan kemampuan para guru sebagai fasilitator (pengelola interaksi sosial) di dalam proses pembelajaran sesuai K-13

2) Penyusunan ulang komposisi materi per mata pelajaran dengan memperhatikan keluasan cakupan dan tingkat kesulitan materi sehingga memudahkan implementasi di dalam proses pembelajaran

3) Penelitian lanjutan untuk mengetahui pola interaksi sosial yang khas pada masing - masing Mapel.

\section{DAFTAR PUSTAKA}

Berger, P. L., \& Luckmann, T. (1990). Tafsir Sosial atas Kenyataan. Penerjemah: Hasan Basari. Jakarta: LP3ES.

Chandra, A., Yusuf, M., \& Rustiyarso. (2013). Interaksi Guru dan Siswa dalam Pembelajaran Sosiologi di SMA. Jurnal Pendidikan dan Pembelajaran Khatulistiwa, 2(6), 1-12. Retrieved from http://jurnal.untan.ac.id/index.php/jpdpb/article/view/2214

Dyer, J., Gregersen, H., \& Christensen, C. M. (2011). The Innovator's DNA: Mastering The Five Skills of Disruptive Innovators (Ke 1 ed.). Boston, Massachusetts: Harvard Business Review Press.

Fahmi, M. N. (2017). Penerapan Pendekatan Saintifik untuk Meningkatkan Aktivitas Belajar dan Hasil Belajar Siswa di SDN Tambakromo 2 Ngawi. Jurnal Pendidikan Dasar Nusantara, 3(1), 106-117. Diunduh dari https://ojs.unpkediri.ac.id/index.php/pgsd/article/view/749

Gee, J. P. (2001). Reading as situated language: A sociocognitive perspective. Journal of Adolescent \& Adult Literacy, 44(8), 714-725. Diunduh dari http://jamespaulgee.com/pdfs/Reading\%20as\%20Situated\%20Language.pdf 
Herawaty, \& Suherman. (2018). Kesulitan Belajar Berlatar Interaksi Sosial Peserta Didik di Sekolah. Journal of Innovative Counseling : Theory, Practice \& Research, 2(1), 20-26.

Hurst, B., Wallace, R., \& Nixon, S. B. (2013). The Impact of Social Interaction on Student Learning. Reading Horizons: A Journal of Literacy and Language Art, 52(4), 375-398. Diunduh dari https://scholarworks.wmich.edu/cgi/viewcontent.cgi?article=3105\&context=reading_hori zons

Komara, E. (2016). Belajar dan Pembelajaran Interaktif (ke2 ed.). Bandung: Refika Aditama.

Mendikbud RI. (2013). Peraturan Mendikbud Nomor 81A Tahun 2013 tentang Implementasi Kurikulum 2013. Jakarta: Kemdikbud RI.

Mendikbud RI. (2016). Peraturan Menteri Pendidikan dan Kebudayaan Nomor 22 Tahun 2016 Tentang Standar Proses Pendidikan Dasar dan Menengah. Jakarta: Kemdikbud RI.

Nugraha, I. S., \& Suherdi, D. (2107). Scientific Approach: An English Learning-Teaching (ELT) Approach in the 2013 Curriculum. Journal of English and Education, 5(2), 112-119.

Okita, S. Y. (2012). Social Interactions and Learning. In N. M. Sell, Encyclopedia of the Sciences of Learning (Vol. 9). Boston, MA: Springer. doi:https://doi.org/10.1007/978-14419-1428-6_1770

Putri, A. F., Utami, B., \& Nugroho, A. (2015). Penerapan Model PBL Disertai Eksperimen Untuk Meningkatkan Interaksi Sosial dan Prestasi Belajar. Jurnal Pendidikan Kimia, 4(4), 27-35.

Sani, R. A. (2017). Pembelajaran Saintifik untuk Implementasi Kurikulum 2013 (4 ed.). Jakarta: Bumi Aksara.

Setiyadi, M. W., Ismail, \& Gani, H. A. (2017). Pengembangan Modul Pembelajaran Biologi Berbasis Pendekatan Saintifik untuk Meningkatkan Hasil Belajar. Journal of Educational Science and Technology, 3(2), 102-112. Diunduh dari https://ojs.unm.ac.id/JEST/article/view/3468 